\title{
PERAN LEMBAGA PENJAMIN SIMPANAN (LPS) PADA BANK GAGAL SEBAGAI UPAYA PERLINDUNGAN HUKUM TERHADAP NASABAH
}

\author{
Nanang1, Sri Anggraini Kusuma Dewi². \\ STMIK Asia Malang \\ kusumadewi2309@gmail.com
}

\begin{abstract}
:
Pada saat ini perkembangan dunia perbankan memberikan kontribusi yang besar terhadap perekonomian di Indonesia. Pada tahun 1998 ketika krisis moneter melanda Indonesia, dunia perbankan seakan guncang karena 16 bank dinilai tidak mampu untuk dapat melunasi hutangnya baik jangka panjang maupun jangka pendek yang mengakibatkan menurunnya kepercayaan masyarakat terhadap sistem perbankan, untuk mengatasi krisis yang terjadi. Pemerintah mengeluarkan beberapa kebijakan diantaranya memberikan jaminan atas seluruh kewajiban pembayaran bank, termasuk simpanan masyarakat (blanket guarantee) yang ditetapkan dalam Keputusan Presiden Nomor 26 Tahun 1998 tentang Jaminan Terhadap Kewajiban Pembayaran Bank Umum dan Keputusan Presiden Nomor 193 Tahun 1998 tentang Jaminan terhadap Kewajiban Pembayaran Bank Perkreditan Rakyat. Lahirnya Undang-Undang Nomor 7 Tahun 2009 pembaharuan dari Undang-Undang Nomor 24 beserta Perpu Nomor 3 Tahun 2008 dan PP Nomor 66 Tahun 2008 diharapkan dapat memberikan kepastian hukum dan rasa keadilan kepada setiap nasabah yang akan menyimpan uangnya di bank. Apabila terjadi kemungkinan-kemungkinan yang tidak diharapkan di dalam dunia perbankan, maka dana nasabah yang terdapat di dalam bank akan tetap aman dan dapat di ambil kembali melalui LPS. Dari uraian di atas, maka permasalahan yang akan dikaji dalam penelitian ini adalah Peran Lembaga Penjamin Simpanan (LPS) pada Bank Gagal sebagai Perlindungan Hukum Terhadap Nasabah.
\end{abstract}

Kata Kunci: Lembaga Penjamin Simpanan, bank gagal, perlindungan hukum, nasabah

\footnotetext{
Abstract

At present, the development of the banking sector contributes to the economy in Indonesia. In 1998, when the monetary crisis hits Indonesia, the banking world seemed to be shaken because 16 banks were considered unable to repay their debts both long and short term which resulted in a decline in public confidence in the banking system to overcome the crisis. The government issued several policies including provide guarantees for all bank payment obligations, including blanket guarantees stipulated in Presidential Decree Number 26/1998 concerning Guarantees for Obligations of Commercial Bank Payments and Presidential Decree Number 193/1998 concerning Guarantees for Payment Payments of Rural Banks. The birth of Law Number 7/2009 renewal of Law
} 
Number 24 along with Perpu Number 3/2008 and Government Regulation Number $66 / 2008$ are expected to provide legal certainty and a sense of justice to every customer who will save his money in the bank. If there are unexpected possibilities in the banking world, the customer funds contained in the bank will remain safe and can be taken back through LPS. From the description above, the problem that will examine in this study is the role of the Deposit Insurance Corporation (LPS) on Failed Banks as Legal Protection against Customers.

Keywords: Deposit Insurance Corporation, failed bank, legal protection, customers

\section{PENDAHULUAN}

Krisis perbankan nasional telah memberikan pelajaran kepada bangsa Indonesia bahwa kegagalan suatu bank pada akhirnya menjadi beban Negara.Rekapitalisasi melalui penerbitan obligasi pada akhirnya membebani APBN secara berkepanjangan.Oleh karena itu wajar kalau dikatakan bahwa kegagalan sebuah bank pada akhirnya menjadi beban masyarakat. Sutan Rem Sjahdeini (2007:122) menyatakan bahwa bank hanya terikat secara hukum dan bertanggung jawab apabila perbuatan pengurus sesuai dengan maksud dan tujuan bank sebagaimana ditentukan dalam anggaran dasar. Jika perbuatan tersebut merupakan perbuatan pribadi pengurus yang tidak ada kaintannya dengan bank, maka pertanggungjawabannya pribadi.Namun, hal tersebut belum dapat menjaga kepercayaan masyarakat terhadap industri perbankan.Hal ini juga melatarbelakangi pemerintah untuk memberikan suatu jaminan kepada masyarakat dalam bentuk peraturan mengenai penjaminan terhadap simpanan nasabah.Akhirnya pada tanggal 22 September 2004, Presiden Republik Indonesia mengesahkan Undang-Undang Republik Indonesia Nomor 24 Tahun 2004 tentang Lembaga Penjamin Simpanan.

Hukum yang baik adalah hukum yang seharusnya memberikan sesuatu yang lebih daripada sekedar prosedur hukum (Philippe Nonet, 2003:59).Hukum tersebut harus berkompeten dan juga adil dan harus mampu mengenali keinginan publik dan upaya komitmen terhadap tercapainya keadilan subtansif.Karena hubungan di dalam industri perbankan merupakan hubungan kepercayaan, maka suatu hubungan menjadi hubungan kepercayaan apabila satu pihak secara nyata tergantung pada pihak lainnya.Pembentukan peraturan LPS dirasakan semakin penting dengan tujuan untuk mengantisipasi agar tidak terulang kembali pengalaman buruk pada tahun 1998.Pengalaman tersebut telah menunjukkan dengan tidak efektifnya hukum telah menyebabkan pertumbuhan ekonomi Asia yang disebut-sebut sebagai keajaiban berubah menjadi kehancuran. Hilangnya kepercayaan masyarakat akan membawa dampak yang sangat serius bagi kelangsungan usaha bank dan pada gilirannya mengakibatkan krisis ekonomi yang parah. Sedangkan keberhasilan reformasi perkonomian tergantung pada berfungsinua 
sistem hukum dengan baik.Oleh karena itu, pemerintah segera membentuk perundang-undangan mengenai penjamin simpanan nasabah yang dikenal dengan Undang-Undang No.24 Tahun 2004 tentang Lembaga Penjamin Simpanan (LPS).

Peran industri perbankan adalah menjaga stabilitas perekonomian suatu negara.Sehingga memberikan jaminan kepada nasabah merupakan salah satu unsur yang paling penting.Apabila suatu bank dilikuidasi maupun dinyatakan sebagai bank gagal, cepat lambatnya penyelesaian pengembalian simpanan nasabah sangat mempengaruhi tingkat kepercayaan masyarakat terhadap sistem perbankan.Hilangnya kepercayaan masyarakat juga berdampak buruk bagi industri perbankan yaitu dengan terjadinya rush. Dalam Undang-Undang Nomor 24 Tahun 2004 tentang Lembaga Penjamin Simpanan kemudian diperbarui dengan Undang-Undang Nomor 7 Tahun 2009 terdapat empat pilihan teknis terhadap bank gagal, yakni, pertama, melalui penanganan bank gagal sistemik dengan melibatkan pemegang saham, kedua, melalui penanganan bank gagal sistemik tanpa melibatkan pemegang saham, ketiga melalui penyelamatan bank gagal tidak sistemik dan keempat, dengan tidak melakukan menyelamatkan pada bank gagal tidak sistemik.

Pendefinisi sistemik dan non-sistemik mempunyai arti yang penting dalam teknis penutupan bank gagal terutama dalam hal penyelamatan yang berarti negara melakukan intervensi pada kelangsungan operasional bank gagal tersebut dan dalam pertemuan G20 hal ini pernah dibahas mengenai pendefinisian dan ukuran dampak dari bank gagal akan tetapi belum juga terdapat kesepahaman pendapat karena hampir semua negara mempunyai pandangan bahwa definisi mengenai sistemik dan non-sistemik masih bersifat relatif karena berdasarkan pada kondisi, sehingga sampai saat ini belum ada penetapan definisi sistemik dan non-sistemik di negara mana pun.

\section{KAJIAN LITERATUR}

\section{Blanket Guarantee}

Pada tahun 1998 Indonesia mengalami krisis moneter dan perbankan yang menghantam Indonesia, yang ditandai dengan dilikuidasinya 16 bank.hal tersebut mengakibatkan menurunnya tingkat kepercayaan masyarakat pada sistem perbankan. Blanket Guarantee merupakan kebijakan yang dikeluarkan pemerintah untuk mengisi kekosongan hukum dalam menjamin nasabah penyimpan. Hal ini ditetapkan dalam Keputusan Presiden Nomor 26 Tahun 1998 tentang Jaminan Terhadap Kewajiban Pembayaran Bank Umum dan Keputusan Presiden Nomor 193 Tahun 1998 tentang Jaminan Terhadap Kewajiban Pembayaran Bank Perkreditan Rakyat 
(http://www1.lps.go.id). Sedangkan lembaga penyelenggara program penjaminan tersebut adalah Badan Penyehatan Perbankan (BPPN) yang didirikan tanggal 26 Januari 1998 berdasarkan Keputusan Presiden No.27 Tahun 1998. Berdasarkan Keppres tersebut, fungsi BPPN pada saat itu melakukan administrasi terhadap program penjaminan bank secara umum yang dikeluarkan noleh pemerinth pada tanggal 27 Januari 1998. Selain itu BPPN juga diminta untuk melakukan pembinaan, restrukturisasi dan penyehatan perbankan terhadap bank yang dinilai BI tidak sehat (Daruri dan Djoni, 2004:57). Tujuan utama pemberian bantuan kepada bank oleh pemerintah menurut Sitompul (2002:107-108), yaitu:

1. Apabila dampak sistematik cukup serius sehingga dipercaya akan mengakibatkan kebangkrutan bank pemerinth kemudian turun tangan memberika jaminan terhadap seluruh kreditur.

2. Bank yang dilikuidasi jarang mampu membayar klaim nasabah penyimpan dan kreditur lainnya dan apabila akhirnya tetap dibayar hampir tidak pernah secara penuh.

3. Apabila bank bermasalah dibantu oleh sistem perbankan atau mendapat bantuan likuiditas dari bank sentral dan kemudian di ambil alih, nasabah penyimpan dan kreditur lainnya tidak megalami kerugian.

Dalam pelaksanaannya, blanket guarantee memang dapat menumbuhkan kembali kepercayaan masyarakat terhadap industri perbankan, namun ruang lingkup penjaminan yang terlalu luas menyebabkan timbulnya moral hazard baik dari sisi pengelola bank maupun masyarakat. Penyaluran Bantuan Likuiditas Bank Indonesia (BLBI) sebagai implementasi pemberlakuan blanket guarantee. Istilah BLBI dikenal sejak tanggal 15 Januari 1998 sebagaimana ditegaskan Pemerintah dalam Letter of Intent (LOI) kepada International Monetary Fund (IMF) yang kemudian disetujui oleh IMF dan menjadi persyaratan yang ditetapkan IMF. BLBI adalah fasilitas Bank Indonesia yang digunakan untuk menjaga kestabilan sistem pembayaran dan sektor perbankan agar tidak terganggu karena ketidakseimbangan (mismatch) antara penerimaan dan penarikan dana pada bank-bank, baik jangka pendek maupun jangka panjang (Sitompul, 2007:146). Bantuan kredit tersebut meliputi sub ordinasi, kredit likuiditas darurat dan fasilitas diskonto I dan II. Akibat diberlakukannya BLBI tersebut membawa impilkasi besarnya beban yang harus ditanggung pemerintah atau negara, karena jaminan simpanan tidak tebatas, bantuan likuiditas yang longgar, rekapitulasi yang berulang, debitur ngemplang serta longgarnya regulasi. Blanket guarantee juga dapat membawa dampak negatif yaitu timbulnya moral hazard baik oleh pengelola bank, pemilik bank maupun kreditur dan 
deposan. Oleh karena itu, pemerintah menghapus sistem blanket guarantee dengan membentuk Lembaga Penjamin Simpanan sebagai langkah antisipasi pembubaran BPPN pada tahun 2004 (Daruri dan Djoni, 2004:129).

\section{Lembaga Penjamin Simpanan sebagai Lembaga Penjamin} Simpanan Nasabah

Lembaga Penjamin Simpanan (LPS) didirikan berdasarkan Undang-Undang LPS yang berfungsi menjamin simpanan nasabah penyimpan (dalam bentuk giro, deposito, sertifikat deposito dan tabungan atau bentuk lainnya atau yang dipersamakan dengan itu).LPS juga harus turut aktif dalam memelihara stabilitas sistem perbankan nasional. Untuk itu, LPS memiliki kewenganan antara lain untuk menetapkan dan memungut premi penjaminan daari bankbank (yang dikumpulkan menjadi dana LPS). Dengan pembayaran premi yang dilkukan oleh bank peserta penjaminan kepada LPS, maka dalam hal terjadi pecabutan izin usaha dan likuidasi bank, pelaksanaan kewajiban bank terhadap nasabah atas simpanannya beralih menjadi tanggung jawab LPS. Lembaga Penjamin Simpanan merupakan penyempurnaan dari program penjaminan pemerintah terhadap seluruh kewajiban bank (blanket guarantee) yang berlaku di tahun 1998 sampai dengan 2005). Kebijakan blanket guarantee disatu sisi dapat meningkatkan kepercayaan masyarakat terhadap perbankan, namun disisi lain kebijakan tersebut telah membebani keuangan negara dan dapat menimbulkan moral hazard bagi perlaku perbankan dan nasabah (Sutedi, 2010:11).

Sutedi (2010:68-67) mengemukakan mengenai simpanan yang dijamin oleh LPS, yaitu:

1. Simpanan yang idjamin meliputi giro, deposito, sertifikat deposito, tabungan, dan/atau bentuk lain yang dipersamakan dengan itu.

2. Simpanan nasabah bank berdasarkan Prinsip Syariah yang dijamin meliputi:

a. Giro berdasarkan Prinsip Wadiah,

b. Tabungan berdasarkan Prinsip Wadiah,

c. Tabungan berdasarkan Prinsip Muharabah muthlaqah atau Prinsip Mudharabah muqayyah yang risikonya ditanggung oleh bank,

d. Simpanan berdasarkan Prinsip Syariah lainnya yang dtetapkan oleh Lembag Pnejamin Simpanan setelah mendapat pertimbangan Lembaga Pengawas Perbankan.

3. Simpanan yang dijamin merupakan simpanan yang berasal dari masyarakat, termasuk yang berasal dari bank lain.

4. Nilai simpanan yang dihamin Lembaga Penjamin Simpanan mencakup saldo pada tanggal pencabutan izin usaha bank.

5. Saldo tersebut berupa: 
a. Pokok tambahan bagi hasil yang telah menjadi hak nasabah, untuk Simpanan yang memiliki komponen bagi hasil yang timbul dari transaksi dengan prinsip syariah;

b. Pokok tambah bunga yang telah menjadi hak nasabah, untuk Simpanan yang memiliki komponen bunga;

c. Nilai sekarang per tanggal pencabutan izin usaha dengan menggunakan tingkat diskonto yang tercatata pada bilyet, untuk Simpanan yang memiliki komponen diskonto.

6. Saldo yang dijamin untuk setiap nasabah pada satu bank adalah hasil penjumlahan saldo seluruh rekening simpanan nasabah pada bank tersebut, baik rekening tunggal maupun rekening-rekening gabungan (joint account).

7. Untuk rekening gabungan (joint account), saldo rekening yang diperhitungkan bagi satu nasabah adalah saldo rekening gabungan tersebut yang dibagi secara prorata dengan jumlah pemilik rekening.

8. Dalam hal nasabah memiliki rekening tunggal dan rekening gabungan (joint account), saldo rekening yang lebih dahulu diperhitungkan adalah saldo rekening tunggal.

LPS tidak akan menbayar klaim penjaminan apabila nilai simpanan nasabah penyimpan melebihi batas maksimal yang akan dijamin LPS.

\section{Hasil Penelitian}

\section{Undang-Undang LPS}

a. Pasal 8 Undang-Undang LPS

b. Pasal 11 Ayat (1)

c. Pasal 12 Ayat (1) dan Pasal 13 Ayat (1) dan Ayat (2) tentang ketentuan pembayaran premi

d. Pasal 16

e. Pasal 19 Ayat (1)

f. Pasal 21

g. Pasal 22 Ayat (1) tentang cara penyelesaian atau penanganan Bank Gagal

h. Pasal 24 Ayat (1) tentang Persyaratan Penyelamatan Bank Gagal yang Tidak Berdampak Sistemik

LPS menetapkan untuk menyelamatkan Bank Gagal yang tidak berdampak sistemik jika dipenuhi persyaratan sebagai berikut:

a. perkiraan biaya penyelamatan secara signifikan lebih rendah dari perkiraan biaya tidak melakukan penyelamatan bank dimaksud; 
b. setelah diselamatkan, bank masih menunjukkan prospek usaha yang baik;

c. ada pernyataan dari RUPS bank yang sekurangkurangnya memuat kesediaan untuk:

1) menyerahkan hak dan wewenang RUPS kepada LPS;

2) menyerahkan kepengurusan bank kepada LPS; dan

3) tidak menuntut LPS atau pihak yang ditunjuk LPS apabila proses penyelamatan tidak berhasil, sepanjang LPS atau pihak yang ditunjuk LPS melakukan tugasnya sesuai dengan peraturan perundang-undangan; dan

d. bank menyerahkan kepada LPS dokumen mengenai:

1) penggunaan fasilitas pendanaan dari Bank Indonesia;

2) data keuangan Nasabah Debitur;

3) struktur permodalan dan susunan pemegang saham 3 (tiga) tahun terakhir; dan

4) informasi lainnya yang terkait dengan aset, kewajiban termasuk permodalan bank, yang dibutuhkan oleh LPS.

i. Pasal 31 tentang Bank Gagal yang Tidak Berdampak Sistemik yang Tidak Diselamatkan

(1) Dalam hal tidak terpenuhinya persyaratan sebagaimana dimaksud dalam Pasal 24 atau LPS memutuskan untuk tidak melanjutkan proses penyelamatan, maka LPS meminta pencabutan izin usaha bank dimaksud sesuai dengan peraturan perundang-undangan.

(2) LPS melaksanakan pembayaran klaim Penjaminan kepada Nasabah Penyimpan bank yang dicabut izin usahanya sebagaimana dimaksud pada ayat (1) sesuai dengan ketentuan dalam Bab IV Bagian Keempat.

j. Pasal 33 Ayat (1) tentang Persyaratan Penanganan Bank Gagal yang Berdampak Sistemik dengan Penyetoran Modal oleh Pemegang Saham

Penanganan Bank Gagal sebagaimana dimaksud dalam Pasal 32 hanya dapat dilakukan apabila:

a. pemegang saham Bank Gagal telah menyetor modal sekurangkurangnya 20\% (dua puluh perseratus) dari perkiraan biaya penanganan;

b. ada pernyataan dari RUPS bank yang sekurangkurangnya memuat kesediaan untuk:

1) menyerahkan kepada LPS hak dan wewenang RUPS;

2) menyerahkan kepada LPS kepengurusan bank; dan

3) tidak menuntut LPS atau pihak yang ditunjuk LPS dalam hal proses penanganan tidak berhasil, sepanjang LPS atau pihak 
yang ditunjuk LPS melakukan tugasnya sesuai dengan peraturan perundang-undangan;

c. bank menyerahkan kepada LPS, dokumen mengenai:

1) penggunaan fasilitas pendanaan dari Bank Indonesia;

2) data keuangan Nasabah Debitur;

3) struktur permodalan dan susunan pemegang saham 3 (tiga) tahun terakhir; dan

4) informasi lainnya yang terkait dengan aset, kewajiban, dan k. Pasal 34 permodalan bank, yang dibutuhkan LPS.

Terhitung sejak LPS menetapkan untuk melakukan penanganan Bank Gagal sebagaimana dimaksud dalam Pasal 33, maka berdasarkan Undang-Undang ini:

a. pemegang saham dan pengurus bank melepaskan dan menyerahkan kepada LPS segala hak, kepemilikan, kepengurusan dan/atau kepentingan lain pada bank dimaksud; dan

b. pemegang saham dan pengurus bank tidak dapat menuntut LPS atau pihak yang ditunjuk LPS dalam hal proses penanganan tidak berhasil, sepanjang LPS atau pihak yang ditunjuk LPS melakukan tugasnya sesuai dengan peraturan

\section{Pasal 39} perundang-undangan.

Dalam hal penanganan Bank Gagal sebagaimana dimaksud dalam Pasal 32 tidak dapat dilakukan, LPS melakukan penanganan Bank Gagal dimaksud tanpa mengikutsertakan pemegang saham.

1. Peraturan Pemerintah Pengganti Undang-Undang Republik Indonesia Nomor 3 Tahun 2008 Tentang Perubahan Atas UndangUndang Nomor 24 Tahun 2004 Tentang Lembaga Penjamin Simpanan

\section{a. Pasal 11}

(1) Nilai Simpanan yang dijamin untuk setiap nasabah pada satu bank paling banyak Rp100.000.000,00 (seratus juta rupiah).

(2) Nilai Simpanan yang dijamin dapat diubah apabila dipenuhi salah satu atau lebih kriteria sebagai berikut:

a. terjadi penarikan dana perbankan dalam jumlah besar secara bersamaan;

b. terjadi inflasi yang cukup besar dalam beberapa tahun;

c. jumlah nasabah yang dijamin seluruh simpanannya menjadi kurang dari 90\% (sembilan puluh per seratus) dari jumlah nasabah penyimpan seluruh bank; atau 
d.terjadi ancaman krisis yang berpotensi mengakibatkan merosotnya kepercayaan masyarakat terhadap perbankan dan membahayakan stabilitas sistem keuangan.

(3) Dalam hal situasi sebagaimana dimaksud pada ayat (2) huruf a dan huruf d sudah teratasi, besaran nilai Simpanan yang dijamin dapat disesuaikan kembali.

(4) Perubahan besaran nilai Simpanan yang dijamin sebagaimana dimaksud pada ayat (2) ditetapkan dengan Peraturan Pemerintah dan selanjutnya dilaporkan kepada Dewan Perwakilan Rakyat.

(5) Penyesuaian besaran nilai Simpanan sebagaimana dimaksud pada ayat (3) ditetapkan dengan Peraturan Pemerintah setelah dikonsultasikan dengan Dewan Perwakilan Rakyat.

(6) Ketentuan lebih lanjut mengenai penentuan nilai Simpanan yang dijamin untuk setiap nasabah penyimpan pada satu bank sebagaimana dimaksud pada ayat (1), diatur dengan Peraturan Lembaga Penjamin Simpanan.

2. Peraturan Pemerintah Republik Indonesia Nomor 66 Tahun 2008 Tentang Besaran Nilai Simpanan Yang Dijamin Lembaga Penjamin Simpanan

\section{a. Pasal 1}

Nilai simpanan yang dijamin untuk setiap nasabah pada satu bank yang semula berdasarkan Pasal 11 ayat (1) Undang-Undang Nomor 24 Tahun 2004 tentang Lembaga Penjamin Simpanan ditetapkan paling banyak Rp100.000.000,00 (seratus juta rupiah), berdasarkan Peraturan Pemerintah ini diubah menjadi paling banyak Rp2.000.000.000,00 (dua miliar rupiah).

\section{b.Pasal 2}

Ketentuan mengenai nilai simpanan yang dijamin sebagaimana dimaksud dalam Pasal 1 tidak berlaku untuk simpanan nasabah bank yang dicabut izin usahanya sebelum Peraturan Pemerintah ini mulai berlaku.

\section{c. Pasal 3}

Peraturan Pemerintah ini mulai berlaku pada tanggal ditetapkan.Agar setiap orang mengetahui, memerintahkan pengundangan Peraturan Pemerintah ini dengan penempatannya dalam Lembaran Negara Republik Indonesia.

\section{Undang-Undang Nomor 10 Tahun 1998 tentang Perbankan}

a. Pasal 37

(1) Dalam hal suatu bank mengalami kesulitan yang membahayakan kelangsungan usahanya, Bank Indonesia dapat melakukan tindakan agar: 
a. Pemegang saham menambah modal;

b. Pemegang saham mengganti dewan komisaris dan atau direksi bank;

c. Bank menghapusbukukan kredit atau pembiayaan berdasarkan Prinsip Syariah yang macet dan memperhitungkan kerugian bank dengan modalnya;

d. Bank melakukan merger atau konsolidasi dengan bank lain;

e. Bank dijual kepada pembeli yang bersedia mengambil alih seluruh kewajiban;

f.Bank menyerahkan pengelolaan seluruh atau sebagian kegiatan bank kepada pihak lain;

g. Bank menjual sebagian atau seluruh harta dan/atau kewajiban bank kepada bank atau pihak lain.

(2) Apabila:

a. Tindakan sebagaimana dimaksud dalam ayat (1) belum cukup untuk mengatasi kesulitan yang dihadapi bank; dan/atau

b. Menurut penilaian Bank Indonesia keadaan suatu bank dapat membahayakan sistem perbankan, Pimpinan Bank Indonesia dapat mencabut izin usaha bank dan memerintahkan direksi bank untuk segera menyelenggarakan Rapat Umum Pemegang Saham guna membubarkan badan hukum bank dan membentuk tim likuidasi.

(3) Dalam hal direksi bank tidak menyelenggarakan Rapat Umum Pemegang Saham sebagaimana dimaksud dalam ayat (2), Pimpinan Bank Indonesia meminta kepada pengadilan untuk mengeluarkan penetapan yang berisi pembubaran badan hukum bank, penunjukan tim likuidasi, dan perintah pelaksanaan likuidasi sesuai dengan peraturan perundang-undangan yang berlaku."

\section{h.Pasal 37 B}

(1) Setiap bank wajib menjamin dana masyarakat yang disimpan pada bank yang bersangkutan.

(2) Untuk menjamin simpanan masyarakat pada bank sebagaimana dimaksud dalam ayat (1) dibentuk Lembaga Penjamin Simpanan.

(3) Lembaga Penjamin Simpanan sebagaimana dimaksud dalam ayat (2) berbentuk badan hukum Indonesia.

(4) Ketentuan mengenai penjaminan dana masyarakat dan Lembaga Penjamin Simpanan, diatur lebih lanjut dengan Peraturan Pemerintah. 


\section{METODE PENELITIAN}

\section{Jenis Penelitian}

Jenis penelitian dalam penelitian ini adalah penelitian hukum normatif dengan didukung oleh data-data empiris.Penelitian hukum normatif dilakukan dengan mempelajari dan mengkaji azas-azas hukum dan kaidah-kaidah atau norma-norma hukum positif yang berasal dari bahan-bahan kepustakaan yang ada, dari peraturan perundang-undangan serta ketentuan-ketentuan hukum yang berkaitan dengan Lembaga Penjamin Simpanan (LPS).

\section{Pendekatan Penelitian}

Pendekatan penelitian menjelaskan pendekatan hukum yang digunakan.Pendekatan yang digunakan di dalam penelitian hukum tersebut yaitu menggunakan pendekatan undang-undang (statute approach).Pendekatan ini dilakukan dengan menelaah semua undangundang dan regulasi yang bersangkut paut dengan isu hukum yang sedang ditangani.

\section{Jenis Bahan Hukum}

Penelitian ini dibutuhkan 3 (tiga) jenis bahan hukum, yaitu bahan hukum primer, bahan hukum sekunder, dan bahan hukum tersier.Penelitian ini juga berusaha menggali 3 (tiga) bahan hukum secara sekaligus dengan harapan keduanya saling mendukung.

a. Bahan hukum primer berupa Undang-Undang Nomor 7 Tahun 1992 dan Undang-Undang Nomor 10 Tahun 1998 tentang Perbankan, Undang-Undang Nomor 7 Tahun 2009 sebagai pembaharuan Undang-Undang No.24 Tahun 2004 tentang Lembaga Penjamin Simpanan, Undang-Undang No.23 Tahun 1999 dan Undang-Undang Nomor 3 Tahun 2004 tentang Bank Indonesia, Undang-Undang Nomor 40 Tahun 2007 tentang Perseroan Terbatas, Perpu Nomor 3 Tahun 2008 tentang Perubahan Atas Undang-Undang Nomor 24 Tahun 2004 tentang Lembaga Penjamin Simpanan, Perpu Nomor 66 Tahun 2008 tentang Besaran Nilai Simpanan yang Dijamin Lembaga Penjamin Simpanan, Perpres Nomor 2 Tahun 2008 tentang Lembaga Penjamin Simpanan dan peraturan-peraturan lain yang berhubungan dengan penelitian ini.

b. Bahan hukum sekunder berupa buku yang berkaitan dengan hukum perbankan dan ekonomi, hasil-hasil penelitian, artikel, hasil seminar atau pertemuan ilmiah lainnya yang relevan dengan penelitian ini.

c. Bahan hukum tertier atau bahan hukum penunjang yang mencakup bahan yang memberi petunjuk-petunjuk dan penjelasan terhadap bahan hukum primer, sekunder seperti kamus umum, kamus hukum, majalah dan jurnal ilmiah, serta bahan-bahan di luar bidang hukum yang relevan dan dapat dipergunakan untuk 
melengkapai data yang diperlukan dalam penelitian ini (Sunggono, 195:2005).

\section{Metode Penelusuran Bahan Hukum}

Menurut Ronny Hanitijo Soemitro, dalam bukunya Metodologi Penelitian Hukum dan Yurimetri, teknik pengumpulan data dalam suatu penelitian dapat dilakukan melalui 4 (empat) cara, yaitu (a) Studi Kepustakaan, (b) Observasi, (c) Interview, dan (d) Kuesioner.

Metode penulusuran bahan hukum pada penelitian tesis ini menggunakan studi kepustakaan (library research), artinya data yang diperoleh melalui penelusuran kepustakaan berupa data sekunder ditabulasi yang kemudian disistematisasikan dengan memilih perangkat-perangkat hukum yang relevan dengan objek penelitian.

4. Teknik Analisis Bahan Hukum

Seluruh data yang sudah diperoleh, dikumpulkan untuk selanjutnya akan ditelaah dan dianalisis. Analisa data penelitian ini dengan menggunakan metode kualitatif. Analisis untuk data kualitatif dilakukan dengan cara pemilihan pasal-pasal yang berisi kaidah-kaidah hukum yang mengatur tentang perlindungan hukum LPS terhadap nasabah dalam hal bank gagal dihubungkan dengan Undang-Undang Nomor 7 Tahun 2009 pembaharuan dari UndangUndang Nomor 24 Tahun 2004 tentang Lembaga Penjamin Simpanan, kemudian membuat sistematika dari pasal-pasal tersebut sehingga akan menghasilkan klasifikasi tertentu sesuai dengan permasalahan yang dibahas dalam penelitian ini.

Penarikan kesimpulan dilakukan secara deduktif, yakni menarik kesimpulan dari suatu permasalahan yang bersifat umum terhadap permasalahan konkret yang dihadapai.Sehingga dapat menjadi acuan dan pertimbangan hukum dalam mengatasi permasalahanpermasalahan yang timbul.

\section{PEMBAHASAN}

\section{Perlindungan Hukum Nasabah oleh Lembaga Simpanan}

Sejak krisis moneter dan perbankan yang terjadi pada tahun 1998, pemerintah membuat kebijakan dengan menerapkan blanket guarantee untuk menjamin simpanan nasabah. Blanket guarantee ini diterapkan pada tanggal 27 Januari 1998. Tetapi kenyataannya, kebijakan tersebut menyebabkan timbulnya moral hazard baik dari sisi pengelola bank maupun masyarakat.Untuk mengatasi hal tersebut dan agar tetap menciptakan rasa aman bagi nasabah penyimpan serta menjaga stabilitas sistem perbankan, program penjaminan yang sangat luas lingkupnya tersebut perlu digantikan dengan sistem penjaminan yang terbatas.Landasan kebijakan pemberian bantuan likuiditas tersebut adalah Undang-Undang Nomor 13 Tahun 1968 
tentang Bank Sentral dan Undang-Undang Nomor 7 Tahun 1992 tentang perbankan sebagaimana telah diubah dengan UndangUndang Nomor 10 tahun 1998. Pasal 32 Ayat (3) Undang-Undang Nomor 13 Tahun 1968 menyebutkan "Bank dapat pula memberikan kredit likuiditas kepada bank-bank untuk mengatasi kesulitasn likuiditas dalam keadaan darurat", sedangkan Pasal 37 Ayat (2) huruf b Undang-Undang Nomor 7 Tahun 1992 menegaskan "Dalam hal suatu bank mengalami kesulitas likuiditas yang membahayakan kelangsungan usahanya, maka BI dapat mengambil tindakan lain sesuai dengan peraturan perundang-undangan yang berlaku".

Dikeluarkannya Undang-Undang Nomor 10 Tahun 1998 tentang Perbankan mengamanatkan pembentukan suatu Lembaga Penjamin Simpanan (LPS) sebagai pelaksana penjaminan dan masyarakat.Pembentukan Undang-Undang Perbankan tersebut dimaksudkan untuk memperkuat landasan hukum bagi bank yang izin usahnya dicabut atau dilikuidasi sehingga nasabah penyimpan tidak dirugikan oleh pihak bank.

Hal tersebut senada dengan pendapat Sutedi (2007:175) bahwa"Disamping itu, bank merupakan badan usaha yang memiliki karakteristik khusus dibandingkan badan usaha pada umumunya. Oleh karena itu, proses likuidasi bank tidak disamakan dengan prosedur yang berlaku pada badan usaha selain bank. dengan demikian, ketentuan undang-undang ini merupakan lex specialis terhadap ketentuan yang bersifat umum. Hal tersebut dimaksudkan untuk memperkokoh landasan hukum bagi kelancaran pencabutan izin usaha, pembubaran badan hukum dan likuidasi bank."

Sebelum dilakukan likuidasi, bank perlu diselamatkan terlebih dahulu.Upaya penyelematan bank ditentukan dalam Pasal 37 Ayat (1) yang menyatakan bahwa sebelum mencabut izin usaha bank, terlebih dahulu dilakukan tindakan-tindakan penyelamatan yaitu penyehatan bank. Apabila upaya penyelamatan tersebut tidak berhasil dicapai, maka BI berwenang untuk melakukan exit policy berupa pencabutan izin usaha, pembubaran badan hukum, dan pelaksanaan likuidasi (Sutedi, 2007:174).

LPS yang menggunakan blanket guarantee merupakan salah satu komponen finacial safety net yang terdiri dari peraturan kehatihatian, pengawan, lender of last resort, dan lembaga penjamin simpanan (Sitompul, 2005:317). Sitompul (2007) juga mengemukakan bahwa:

"Penggantian blanket guarantee dengan LPS dilakukan pada saat kepercayaan masyarakat telah pulih, sistem perbankan telah berhasil direstrukturisasi, krisis telah berlalu, perekonomian telah pulih, makro ekonomi telah dapat mendukung kesehatan bank, 
pemerintah telah memiliki dan siap menerapkan exit policy bagi bank yang tidak sehat, terdapat sistem akuntansi, keterbukaan dan sistem hukum yang kuat, kerangka ketentuan kehati-hatian dan pengawasan telah berjalan dan masyarakat telah diinformasikan secara cukup tentang perubahan cakupan jaminan yang akan diberlakukan".

Untuk itu, maka pembentukan LPS merupakan keharusan dan diback-up negara berdasarkan Undang-Undang, tidak cukup dengan peraturan pemerintah. Karena dengan adanya LPS maka simpanan nasabah di bank akan terjamin. Adanya LPS juga akan mengurangi beban pemerintah, menghindari perilaku moral hazard pengelola bank, dan membangkitkan tanggung jawab dan mendorong pengelola untuk profesional melalui keanggotaan wajib bank dalam LPS.

Daruri dan Djoni (2004:127) mengemukakan bahwa beberapa negara yang telah menerapkan LPS, kebanyakan lebih dikarenakan untuk melindungi deposan kecil, menjaga kepercayaan pasar dan stabilitas sistem keuangan.Karena tujuan dari LPS itu sendiri untuk memberikan jaminan simpanan terhadap deposan kecil.Untuk itu, bank harus memberikan perlindungan yang lebih kuat kepada nasabah dengan menjamin hak-hak nasabah dalam bertransaksi dengan bank yang bertujuan untuk menjaga kepercayaan masyarakat.

Sutedi mengemukakan mengenai simpanan yang dijamin oleh LPS, yaitu:

1. Simpanan yang dijamin meliputi giro, deposito, sertifikat deposito, tabungan, dan/atau bentuk lain yang dipersamakan dengan itu.

2. Simpanan nasabah bank berdasarkan Prinsip Syariah yang dijamin meliputi:

a. Giro berdasarkan Prinsip Wadiah,

b. Tabungan berdasarkan Prinsip Wadiah,

c. Tabungan berdasarkan Prinsip Muharabah muthlaqah atau Prinsip

Mudharabah muqayyah yang risikonya ditanggung oleh bank,

d.Simpanan berdasarkan Prinsip Syariah lainnya yang dtetapkan

oleh Lembag Pnejamin Simpanan setelah mendapat pertimbangan

Lembaga Pengawas Perbankan.

3. Simpanan yang dijamin merupakan simpanan yang berasal dari masyarakat, termasuk yang berasal dari bank lain.

4. Nilai simpanan yang dihamin Lembaga Penjamin Simpanan mencakup saldo pada tanggal pencabutan izin usaha bank.

5. Saldo tersebut berupa: 
a. Pokok tambahan bagi hasil yang telah menjadi hak nasabah, untuk Simpanan yang memiliki komponen bagi hasil yang timbul dari transaksi dengan prinsip syariah;

b. Pokok tambah bunga yang telah menjadi hak nasabah, untuk Simpanan yang memiliki komponen bunga;

c. Nilai sekarang per tanggal pencabutan izin usaha dengan menggunakan tingkat diskonto yang tercatata pada bilyet, untuk Simpanan yang memiliki komponen diskonto.

6. Saldo yang dijamin untuk setiap nasabah pada satu bank adalah hasil penjumlahan saldo seluruh rekening simpanan nasabah pada bank tersebut, baik rekening tunggal maupun rekening-rekening gabungan (joint account).

7. Untuk rekening gabungan (joint account), saldo rekening yang diperhitungkan bagi satu nasabah adalah saldo rekening gabungan tersebut yang dibagi secara prorata dengan jumlah pemilik rekening.

8. Dalam hal nasabah memiliki rekening tunggal dan rekening gabungan (joint account), saldo rekening yang lebih dahulu diperhitungkan adalah saldo rekening tunggal.

Likuidasi bank akan menimbulkan dampak yang negatif di masyarakat. Sutedi (2010:132) mengungkapkan bahwa likuidasi suatu bank dapat mengguncangkan kepercayaan masyarakat terhadap sistem perbankan dan menimbulkan keresahan sosial. Sjahdeni (Tanpa tahun:1) menyatakan likuidasi merupakan tindakan pemberesan terhadap harta kekayaan atau aset dan kewajibankewajiban suatu perusahaan sebagai tindak lanjut daru bubarnya perusahaan. Sedangkan Usman (2003:167) mengemukakan bahwa likuidasi tidak terbatas pada pencabutan usaha bank, tetapi lebih luas lagi termasuk tindakan pembubaran badan hukum bank dan penyelesaian atau pemberesan seluruh hak dan kewajiban bank sebagai akibat dibubarkannya badan hukum bank tersebut.

Djumhana (2001:212) mengemukakan bahwa likuidasi bank dapat dilkukan dengan cara sebagai berikut:

1. Pencairan harta dan atau penagihan piutang kepada para debitur diikuti dengan pembayaran kewajiban bank kepada para kreditur dari hasil pencairan atau penagihan tersebut.

2. Pengalihan seluruh harta dan kewajiban bank kepada pihak lain berdasarkan persetujuan LPS.

Tindakan LPS terhadap Bank Gagal yang dilikuidasi yang dicabut izin usahanya menurut Pasal 43 Undang-Undang LPS, adalah:

1. melakukan kewenangan dalam hal penanganan dan penyelesaian Bank Gagal. 
2. memberikan talangan untuk pembayaran gaji pegawai yang terutang dan talangan pesangon pegawai sebesar jumlah minimum pesangon.

3. melakukan tindakan yang diperlukan dalam rangka pengamanan aset bank sebelum proses likuidasi dimulai.

4. memutuskan pembubaran badan hukum bank, membentuk tim likuidasi, dan menyatakan status bank sebagai bank dalam likuidasi.

Dalam hal bank yang dicabut izin usahnya atas permintaan pemegang saham, LPS tidak membayar klaim penjaminan nasabah penyimpan (Sitompul, 2007:220). Hal ini karena LPS hanya bertanggung jawab pada dana penjaminan sehingga berwenang untuk mengeluarkan dan menjalankan peraturan yang berkaitan dengan keamanan dan kesehatan bank. Peran LPS dalam likuidasi Bank Gagal yaitu bertindak sebagai likuidator untuk menggantikan nasabah penyimpan dana (Sutedi, 2010:175). LPS diharapkan dapat menjalankan proses pemberesan aset dan penyelelsaian kewajiban dari bank yang dicabut izin usahanya secara efektif dan efisien sesuai dengan ketentuan yang berlaku, serta dapat mengoptimalkan tingkat pengembalian dana pinjaman yang telah dikeluarkan oleh LPS tanpa intervensi dari pemegang saham.

Jadi dapat disimpulkan bahwa perlindungan hukum yang diberikan LPS kepada nasabah penyimpan yaitu menjamin dana simpanan nasabah bank. Anggota LPS yaitu semua bank yang beroperasi di Indonesia kecuali Badan Kredit Desa sebagaimana dijelaskan di dalam Pasal 8 Undang-Undang LPS. Sedangkan untuk nilai simpanan yang dijamin LPS setiap nasabah pada satu bank berdasarkan Pasal 11 Ayat (1) Undang-Undang LPS ditetapkan paling banyak Rp. 100.000.000,00 (seratus juta rupiah), kemudian berdasarkan Peraturan Pemerintah Nomor 66/2008 jumlah tersebut diubah menjadi paling banyak Rp 2.000.000.000,00 (dua milyar rupiah).

\section{Bentuk dan Implemetasi Penjaminan terhadap Simpanan Dana Nasabah}

Setiap bank yang menjadi anggota LPS wajib membayar premi penjaminan kepada LPS. Berdasarkan Pasal 12 Ayat (1) Undang-Undang LPS bahwa premi penjaminan diabayarkan dua kali dalam satu tahun pada periode 1 Januari sampai dengan 30 Juni, dan 1 Juli sampai dengan 31 Desember. Perhitungan premi tersebut dihitung sendiri oleh bank.Penetapan jumlah premi yang harus dibayar untuk setiap periode sebagaimana dimaksud dalam Pasal 13 Ayat (1) yaitu 0,1\% dari rata-rata saldo bulanan total Simpanan dalam setiap periode. Premi penjamin dapat ditambah atau dikurangi sesuai 
dengan realisasi rata-rata saldo bulanan total simpanan pada periode yang bersangkutan.

Hal tersebut dijelaskan juga oleh Sitompul (2007:291) bahwa

"Besarnya premi yang dibutuhkan untuk menjaga tersedianya dana yang cukup bergantung pada kondisi sistem perbankan dan prospeknya ke depan. Pada tahun 1999 kisaran premi yang dibebankan kepada bank dimulai dari (untuk sementara) 0\% dari simpanan bagi bank yang sangat kuat di Amerika Serikat sampai terendah 0,005\% di Bangladesh dan setinggi 2\% di Venezuela".

Pasal 15 Undang-Undang LPS menetapkan bahwa cara penetapan premi dapat diubah sehingga tingkat premi menjadi berbeda antara satu bank dan bank lain berdasarkan skala resiko pada kegagalan bank dengan perbedaan yang tidak melebihi 0,5\%. Penjaminan simpanan membutuhkan pendanaan secara mandiri untuk meningkatkan para bankir menjaga banknya agar tetap sehat.Dana tersebut harus cukup untuk memenuhi seluruh permintaan pada saat normal.

Pasal 10 Undang-Undang LPS menetapkan bahwa LPS menjamin simpanan nasabah bank yang berbentuk giro, deposito, sertifikat deposito, tabungan, dan/atau bentuk lainnya yang dipersamakan dengan itu. Sedangkan Pasal 11 Undang-Undang LPS menetapkan bahwa nilai simpanan yang dijamin untuk setiap nasabah pada suatu bank paling banyak Rp 100.000.000,00 (seratus juta rupiah).Berdasarkan Peraturan Pemerintah No.66 Tahun 2008 menetapkan bahwa simpanan yang dijamin untuk setiap nasabah pada suatu bank diubah menjadi paling banyak Rp 2.000.000.000,00 (dua milyar rupiah) dan selebihnya dijamin oleh bank yang bersangkutan dalam bentuk kepercayaan.Karena secara filosofis tujuan utama pendirian LPS adalah untuk menjamin sebagian besar nasabah penyimpan (http://www.lps.go.id).Dimana jumlah penjamin tersebut telah melindungi $95 \%$ nasabah.Apabila bank yang menjadi anggota LPS dicabut izin usahanya, maka LPS wajib membayar klaim penjaminan kepada nasabah penyimpan.sedangkan simpanan yang tidak layak dibayar diatur dalam Pasal 19 Ayat (1) yaitu (1) data Simpanan nasabah dimaksud tidak tercatat pada bank; (2) nasabah Penyimpan merupakan pihak yang diuntungkan secara tidak wajar; dan/atau (3) nasabah Penyimpan merupakan pihak yang menyebabkan keadaan bank menjadi tidak sehat.

Simpanan nasabah yang tidak dijamin dalam hubungan non kontraktual berdasarkan Undang-Undang LPS adalah sebagai berikut:

1. Simpanan nasabah yang melebihi nilai Rp. 2.000.000.000,00 (dua milyar rupiah); 
2. Simpanan nasabah yang berdasarkan hasil rekonsiliasi dan/atau verifikasi memenuhi ketentuan Pasal 19 Undang-Undang LPS.

Simpanan nasabah yang tidak dijamin tersebut, maka nasabah dapat mengajukan hukum ke pengadilan.Untuk ketentuan selanjutnya, menurut Pasal 20 Undang-Undang LPS, apabila nasabah masih merasa dirugikan, maka nasabah dapat mengajukan keberatan kepada LPS yang didukung dengan bukti nyata dan jelas, atau melakukan upaya hukum. Apabila pihak pengadilan mengabulkan upaya hukum nasabah penyimpan, LPS hanya membayar simpanan nasabah tersebut sesuai dengan Penjaminan.Berdasarkan uraian di atas, apabila simpanan yang tidak dijamin oleh LPS karena nilai simpanannya melebihi batas maksimal penjaminan yang ditentukan yaitu Rp. 2.000.000.000,00, maka nasabah penyimpan dapat melakukan upaya hukum sebagai berikut:

1. Berdasarkan hubungan kontraktual, nasabah penyimpan dapat mengajukan upaya hukum ke Pengadilan dengan mengajukan gugatan atas dasar wanprestasi yaitu tidak mengembalikan dana simpanan nasabah beserta bunganya sesuai dengan ketentuan yang disepakati.

2. Berdasarkan hubungan non kontraktual, nasabah penyimpan akan mendapatkan cairan aset bank yang dilikuidasi yang diatur dalam Pasal 54 Ayat (1) Undang-Undang LPS.

\section{PENUTUP}

1. LPS merupakan lembaga penjamin simpanan yang dibentuk berdasarkan Undang-Undang Nomor 24 Tahun 2004. Di dalam Undang-Undang LPS disebutkan mengenai: (1) fungsi, tugas, dan wewenang LPS; (2) prosedur penjaminan LPS dan dana yang dijamin oleh LPS; (3) penyelesaian dan penanganan Bank Gagal; (4) likuidasi Bank Gagal; (5) Organisasi LPS; (6) kekayaan, pembiayaan, dan pengelolaan LPS; (6) rencana kerja dan anggaran LPS; (7) pelaporan kegiatan LPS; (8) kerahasiaan data LPS; dan (9) sanksi administratif dan pidana pada bank yang melanggar ketentuan. Pasal 4 UndangUndang LPS menjelaskan fungsi LPS diantaranya adalah menjamin simpanan nasabah penyimpan dan turut aktif dalam memelihara stabilitas sistem perbankan sesuai dengan kewenangannya. Fungsi LPS dalam penanganan Bank Gagal yaitu menjamin dana nasabah dan melakukan penanganan dan penyelamatan Bank Gagal. Sedangkan tugas LPS disini adalah (1) merumuskan, menetapkan dan melaksanakan kebijakan dalam upaya penyelamatan Bank Gagal yang tidak berdampak sistemik; dan (2) melaksanakan penanganan Bank Gagal yang berdampak sistemik.

2. Tanggung jawab bank terhadap nasabah penyimpan karena pemegang saham meminta pencabutan izin usaha, maka pemegang 
saham wajib mengganti semua kerugian nasabah penyimpan dengan menjual aset bank sesuai dengan Pasal 54 Ayat (5) Undang-Undang Perbankan. Untuk mempermudah tanggung jawab tersebut, maka bank wajib menjadi anggota LPS. Ketentuan kepesertaan LPS diatur dalam Pasal 8 dan Pasal 9 Undang-Undang LPS sehingga tanggung jawab nasabah akan dialihkan kepada LPS sesuai dengan peraturan yang berlaku.

3. Bentuk perlindungan hukum yang diberikan LPS terhadap nasabah penyimpan yaitu jaminan terhadap dana simpanan nasabah. Simpanan yang dijamin meliputi giro, deposito, sertifikat deposito, tabungan, dan/atau bentuk lain yang dipersamakan dengan itu. Setiap bank yang menjadi anggota LPS wajib untuk membayar premi yaitu sebesar $0,1 \%$ dari rata-rata saldo bulanan total Simpanan dalam setiap periode. Sedangkan nilai simpanan yang dijamin untuk setiap nasabah pada suatu bank paling banyak Rp 2.000.000.000,00 (dua milyar rupiah) dan selebihnya dijamin oleh bank yang bersangkutan dalam bentuk kepercayaan. Nasabah dapat melakukan upaya hukum untuk simpanan yang tidak dijamin karena melebihi batas yang ditentukan LPS sebagai berikut: (1) berdasarkan hubungan kontraktual, nasabah penyimpan dapat mengajukan upaya hukum ke Pengadilan dengan mengajukan gugatan atas dasar wanprestasi yaitu tidak mengembalikan dana simpanan nasabah beserta bunganya sesuai dengan ketentuan yang disepakati. (2) berdasarkan hubungan non kontraktual, nasabah penyimpan akan mendapatkan cairan aset bank yang dilikuidasi yang diatur dalam Pasal 54 Ayat (1) UndangUndang LPS.

\section{DAFTAR PUSTAKA}

Anwar, Yesmil, and ADang. 2008. Pembaharuan Hukum Pidana. Jakarta: Grasindo.

Fuady, Munir. 2002. Doktrin-Doktrin Modern Dalam Corporate Law dan Eksistensinya Dalam Hukum Indonesia. Bandung: Citra Aditya Bakti.

Hamdan, M. 1997. Politik Hukum Pidana. Jakarta: PT. Raja Grafindo Persada.

Hamzah, Andi. 1994. Asas-Asas Hukum Pidana. Jakarta: Rineka Cipta.

Lokollo, J.E. 1986. Pidana Denda dalam KUHP Baru. Jakarta: BPHN.

Muladi, and Barda Nawawi Arief. 2006. Tindak Pidana Mayantara Perkembangan Kajian Cyber Crime di Indonesia. Jakarta: Raja Grafindo Persada.

Mulyadi, Mahmul, and Feri Antoni Surbakti. 2010. Politik Hukum Pidana Terhadap Kejahatan Korporasi. Jakarta: PT. Sofmedia. 
Reksodiputro, and Mardjono. 1993. Tindak Pidana Korporasi dan Pertanggungjawabannya Perubahan Wajah pelaku Kejahatan di Indonesia. Jakarta: Pusat Pelayanan Keadilan dan Pelayanan Hukum. 